\title{
Determination of bacterial loads of ice cream in Dinajpur District, Bangladesh
}

\author{
Md. Kamrul Hasan ${ }^{1}$, Dr. Md. Mostafizer Rahman ${ }^{1}$, Dr. Md. Shahidur Rahman Khan ${ }^{2}$, Farzana Afroz $^{1 *}$ \\ ${ }^{1}$ Department of Microbiology, Faculty of Veterinary and Animal Science, Hajee Mohammad Danesh Science and Technology University, \\ Dinajpur-5200, Bangladesh.
}

${ }^{2}$ Department of Microbiology and Hygiene, Bangladesh Agricultural University, Mymensingh-2202, Bangladesh.

*Corresponding Author: Farzana Afroz, Lecturer, Department of Microbiology, Faculty of Veterinary And Animal Science, Hajee Mohammad Danesh Science and Technology University, Dinajpur-5200, Bangladesh, E-mail: farzana.afroz2010@gmail.com

\begin{abstract}
The present study was conducted for the determination of bacterial loads of ice cream. A total of nine samples of three brands-Igloo, Polar and Kwality were collected from local market from Dinajpur during the period from July to December, 2012. Thereafter, microbiological attribute were analyzed and studied comparatively. Total viable count (TVC), total Escherichia coli counts (TEC) and total Staphylococcal counts (TSC) were performed according to the American Public Health Association, using plate count agar medium for TVC and Eosin methylene blue (EMB) agar media for total E. coli count and Staphylococcus agar no. 110 for total Staphylococcal count. The average TVC counts/ml of Igloo, Polar and Kwality were $1.19 \times 10^{4} \mathrm{CFU} / \mathrm{ml}(\log 4.1), 1.39 \times 10^{4} \mathrm{CFU} / \mathrm{ml}(\log 4.1)$ and $8.53 \times 10^{3} \mathrm{CFU} / \mathrm{ml}(\log 3.9)$ respectively. It was found that the highest extent of microbial contamination and proliferation of viable bacteria occurred in Polar ice cream The average E. coli counts obtained from the study was in Igloo $9.26 \times 10^{3} \mathrm{CFU} / \mathrm{ml}(\log 4.0)$, in Polar $1.14 \times 10^{3} \mathrm{CFU} / \mathrm{ml}(\log 3.0)$ and in Kwality $7.95 \times 10^{2} \mathrm{CFU} / \mathrm{ml}(\log 2.9)$. The presence of numbers of E. coli in Igloo ice cream was little bit high indicated the poor hygienic practices during manufacture, post process contamination and unsatisfactory transportation. Statistically the E. coli were more closely related to total viable counts than the Staphylococcal counts. The average Staphylococcal counts in the samples of Igloo, Polar and Kwality were $2.60 \times 10^{3} \mathrm{CFU} / \mathrm{ml}(\log 3.4), 0.0 \mathrm{CFU} / \mathrm{ml}(\log 0.0)$, and $0.0 \mathrm{CFU} / \mathrm{ml}(\log 0.0)$, respectively. The results demonstrated that kwality ice creams are of the superior quality product in respect of sanitary condition.
\end{abstract}

Key words: Ice cream, Total viable count, E. coli, Staphylococcus spp, CFU.

(C) 2013 Microbes and Health. All rights reserved

\section{Introduction}

Throughout the world, there are numerous kinds of milk products (FAO, 1995). Ice cream is a delicious, wholesome, nutritious frozen dairy food. It is made of milk, sweet cream, skim milk, condensed milk or other concentrated dairy products or a combination of these with added sugar, flavoring and stabilizer with or without color and with incorporation of air during the freezing process. Ice cream is undoubtedly one of most popular and favorite food product in Bangladesh among children and adults especially during summer season.

Hazard Analysis Critical Control Points (HACCP) is a systematic approach used in the food industry for the identification, assessment, and control of biological, chemical, and physical hazards providing an effective way to advance food quality/safety, focusing on preventing hazards and improving processes (Swanson \& Anderson 2000).

HACCP implementation generally improves the microbiological quality of food products (Soriano et al. 2002). The evaluation of the microbiological testing results can give important information not only on the quality of the foodstuff at a specific stage of its processing, but on the overall efficiency of HACCP design and implementation as well (Kokkinakis \& Fragkiadakis 2007).

HACCP implementation generally improves the microbiological quality of food products (Soriano et al. 2002). The evaluation of the microbiological testing results can give important information not only on the quality of the foodstuff at a specific stage of its processing, but on the overall efficiency of HACCP design and implementation as well (Kokkinakis \& Fragkiadakis 2007).

The microbiological quality of ice cream can be low, as it is a good growth-medium for microbes due to its nutrients (lactose, proteins, etc) and to its almost neutral $\mathrm{pH}$ of 6-7 (Kanbakan et al. 2004). Time-dependent heating during the ice cream production reduces largely the vegetative forms of the microorganisms. On the other hand, spore bearing microorganisms may pose risks through consumption of this kind of milk products. Furthermore, the presence of pathogens in ice cream samples is mostly due to tools and equipments, water, workers, environment, packaging materials and contaminations during the transportation and distribution of ice cream.

Many diseases are transmitted through milk and its derivatives (Gran et al., 2002). Many psychrophiles and psychrotolerant microorganisms like Listeria monocytogens (WHO 1998), Staphylococcus aureus (Massa et al. 1989), Bacillus (Torkar \& Mozina 2000), Salmonella (Vought \& Tatini 1998), Shigella, Streptococus, Pseudomonas, Campylobacter, Brucella, E. coli and other bacteria are generally present in ice cream.

The total bacteria count can be employed as indicator of the sanitary quality of the product which informs us about the quality of production operations, transport and storage (Hassainya et al., 2006). In certain situation Staphylococci organisms particularly $S$. aureus may be a pathogen, a source of enterotoxin and indicator of unsanitary practice. In man, the main reservoir of S. aureus is the nasal cavity and skin. From these sources Staphylococci find their way into air and dust, into clothings and in other place from 
which foods get contaminated. Since Staphylococcal food poisoning is an intoxication and depends on the ability of food concerned to support the growth of the Staphylococci which produce the toxin. It is therefore important to consider that the processing and handling of the food products should be so designed to minimize contamination and to make unfavorable medium for the growth of these organisms.

The Centre for Food Safety (CFS) announced the findings of a targeted food surveillance project to assess the microbiological quality of ice-cream and frozen confections today. In developed countries ice cream receives quality control measures to increase its shelf life as well as to prevent potential threat of public health. Bangladesh is still backward in this respect. Due to non enforcement of inspection act and lack of maintenance of standard relation to hygienic quality of ice cream , the consumers are deprived of getting quality ice cream in our country. Some commercial company have been marketed ice cream in the local market. It is essential to create awareness among the consumers about the microbiological quality of ice cream. Therefore the present work was conducted to determine the total bacterial load in some popular varieties of ice cream samples in Dinajpur district.

\section{Materials and Methods}

\section{Study area and duration}

The study was conducted during the period from July, 2012 to December, 2012. Ice cream samples were collected from the local market of Dinajpur district of Bangladesh and brought to the Department of Microbiology, Hajee Mohammad Danesh Science and Technology University for laboratory analysis.

\section{Enumeration of total viable count (TVC)}

For the determination of total bacterial count, $1 \mathrm{ml}$ of each tenfold dilution was transferred and spread on five plate count agars using a fresh pipette for each dilution. The plates were then kept in an incubator at $30^{\circ} \mathrm{C}$ for $24-48$ hours. Following incubation plates exhibiting 30-300 colonies were counted. The total viable count was calculated according to ISO. The results of the total bacterial count were expressed as the number of organism or colony forming units per gram (CFU/gm) of ice cream sample.

\section{Enumeration of total $E$. coli count (TEC)}

For the determination of total E.coli count $1 \mathrm{ml}$ of each tenfold dilution was transferred to EMB agar. For each dilution five test plates containing EMB agar were used. All the agar plates were incubated at $30^{\circ} \mathrm{C}$ temperature for 48 hours. The total coliform count was calculated according to ISO. The results of the tota coliform count were expressed as the number of organism or colony forming units per gram $(\mathrm{CFU} / \mathrm{gm})$ of ice cream sample.

\section{Enumeration of total Staphylococcal Count (TSC)}

For the determination of total Staphylococcal count $1 \mathrm{ml}$ of each tenfold dilution was transferred to staphylococcus agar no.110 agar. For each dilution five test plates containing Staphylococcus agar no.110 agar were used. All the agar plates were incubated at $37^{\circ} \mathrm{C}$ tem-perature for 48 hours. The total staphylococcal count was calculated according to ISO. The results of the total Staphylococcal count were expressed as the number of organism or colony forming units per gram $(\mathrm{CFU} / \mathrm{gm})$ of ice cream sample.

\section{Characterization of bacteria}

Cultural characterization

Isolation and identification of E. coli and Staphylococcus spp were performed as per procedures described by Merchant and Packer (1967) and (Carter, 1979). Primary culture was performed in Nutrient agar and Nutrient broth media. Sub-culturing was performed in eosin methylene blue (EMB) agar, MacConkey (MC) agar, Staphylococcus agar no.110 to obtain pure culture and to study the cultural characteristics.

Morphological characterization

The representative E. coli and Staphylocopcci isolates stained by Gram staining (Merchant and Packer, 1967). Motility test was performed by Hanging drop preparation.

Biochemical characterization

Isolated organisms were subjected to biochemical tests viz. sugar fermentation test, triple sugar iron (TSI) agar slant reaction, methyl red-Voges Proskauer (MR-VP) test, indole reaction, and motility indole urease (MIU) test as described by Ali et al. (2008).

\section{Results and Discussion}

Average total viable bacterial load $/ \mathrm{ml}$ of Igloo, Polar, and Kwality were $1.19 \times 10^{4} \mathrm{CFU} / \mathrm{ml}(\log 4.1), 1.39 \times 10^{4} \mathrm{CFU} / \mathrm{ml}$ $(\log 4.1)$ and $8.53 \times 10^{3} \mathrm{CFU} / \mathrm{ml}(\log 3.9)$ respectively. The average $E$. coli counts $/ \mathrm{ml}$ of Igloo, Polar and Kwality were $9.26 \mathrm{x}$ $10^{3} \mathrm{CFU} / \mathrm{ml}, 1.14 \times 10^{3} \mathrm{CFU} / \mathrm{ml}$ and $7.95 \times 10^{2} \mathrm{CFU} / \mathrm{ml}$ respectively. The average Staphylococcal counts/ml of Igloo, Polar and Kwality were $2.60 \times 10^{3} \mathrm{CFU} / \mathrm{ml}, 0.0 \mathrm{CFU} / \mathrm{ml}$ and 0.0 $\mathrm{CFU} / \mathrm{ml}$ respectively.

The assessment of total viable count has clearly provided information that the ice cream samples of Kwality were of the superior quality, because the counts were less than the recommended microbiological standard of Food and Drug administration and USPHS. All brands of ice cream samples were within acceptable limit of public health safety because the samples did not exceed the total viable count $(1,00,000 \mathrm{CFU} / \mathrm{ml})$ permitted under regulation.

The present study showed that $E$. coli counts were highest in igloo and the lowest in kwality ice cream (Table 1). It is evident from the result that the average $E$. coli count was $3.72 \times 10^{3}$ CFU/ml $(\log 3.3)($ Table 1$)$. The E. coli standards for ice cream should not be over $10 / \mathrm{ml}$. However, this study demonstrated that the samples of kwality met the recommended criteria of USPHS. Hence, it could be taken into consideration as superior quality ice cream.

Table 1. Density of average total viable bacteria and other in per gram of ice cream samples of different brands

\begin{tabular}{|c|c|c|c|c|c|c|c|}
\hline $\begin{array}{c}\text { Name of ice } \\
\text { cream samples }\end{array}$ & $\begin{array}{c}\text { No. of samples } \\
\text { analyzed }\end{array}$ & \multicolumn{2}{|c|}{ Total viable count/ml } & \multicolumn{2}{|c|}{ E. coli count/ml } & \multicolumn{2}{|c|}{ Staphylococcal count/ml } \\
\cline { 3 - 8 } & & CFU & Log & CFU & Log & CFU & Log \\
\hline \hline Igloo & 3 & $1.19 \times 10^{4}$ & 4.1 & $9.26 \times 10^{3}$ & 4.0 & $2.60 \times 10^{3}$ & 3.4 \\
\hline \hline Polar & 3 & $1.39 \times 10^{4}$ & 4.1 & $1.14 \times 10^{3}$ & 3.0 & 0.0 & 0.0 \\
\hline \hline Kwality & 3 & $8.53 \times 10^{3}$ & 3.9 & $7.95 \times 10^{2}$ & 2.9 & 0.0 & 0.0 \\
\hline
\end{tabular}

In this study, E. coli counts positively and significantly correlated with total viable count of different brands of commercial ice cream. A ratio relationship obtained between $E$. coli count and total viable count of three brands of ice cream, separately. The $E$. coli count : TVC were in case of Igloo 1: 1.2804, Polar, 1: 12.1963 and Kwality 1: 10.7430 (Table 2). From this result, a 
conclusion could be drawn that higher density of total viable count always contained less number of $E$. coli, since $E$. coli is the index of sanitary quality, the ice cream samples of Kwality were best and also have been found to possess the property of hygienically produced ice cream.

It is known that Staphylococcus play role in determining the hygienic quality index of food. The average Staphylococcal counts $/ \mathrm{ml}$ in different brand of ice cream samples were Igloo 2.60 x $10^{3} \mathrm{CFU} / \mathrm{ml}(\log 3.4)$, Polar 0.0 CFU/ml $(\log 0.0)$, and Kwality $0.0(\log 0.0)$ (Table 1). In this study, Staphylococcal counts were positively and significantly correlated with total viable count in different brands of commercial ice cream, ratio of staphylococcal count : TVC were in case of Igloo 1: 4.5664, Polar, 1: $\alpha$ and Kwality 1: $\alpha$ (Table 2). Microbial quality of ice cream examined in Nepal by Joshi et al. (2004) in Hongkong by Food and Environmental Hygiene Department, in Phillipines by Orallo et al. (1999) and in India by Bhusan Reddy et al.(1994) also reported the more or less comparable results.

Table 2. Ratio relationship between total viable bacterial count and E. coli and Staphylococcal density per/ml portion of ice cream samples of different brands

\begin{tabular}{|c|c|c|c|c|c|c|}
\hline Brand & $\begin{array}{l}\text { No. of sample } \\
\text { analyzed }\end{array}$ & $\begin{array}{l}\text { Average total } \\
\text { viable } \\
\text { count } / \mathrm{ml}\end{array}$ & $\begin{array}{l}\text { Average } E \text {. } \\
\text { coli count } / \mathrm{ml}\end{array}$ & $\begin{array}{l}\text { Ratio of } E \text {. } \\
\text { coli count : } \\
\text { TVC }\end{array}$ & $\begin{array}{c}\text { Average } \\
\text { staphylococcal } \\
\text { count } / \mathrm{ml}\end{array}$ & $\begin{array}{c}\text { Ratio of } \\
\text { staphylococcal } \\
\text { count : TVC }\end{array}$ \\
\hline Igloo & 3 & 11850 & 9255 & 1: 1.2804 & 2595 & $1: 4.5664$ \\
\hline Polar & 3 & 13855 & 1136 & 1: 12.1963 & 0.0 & $1: \alpha$ \\
\hline Kwality & 3 & 8530 & 794 & 1: 10.7430 & 0.0 & $1: \alpha$ \\
\hline
\end{tabular}

The results demonstrated that Kwality ice cream is the best quality product in respect of bacteriological context as well as hygienic point of view. Saha et al. (2012) found Ice cream from Kwality Company was superior to other companies on the basis of chemical and microbial parameters, which is more or less similar to the present study.

Characterization results of the study indicated that the ice cream samples contained Gram positive nonmotile and Gram negative motile organisms, colony characteristics in special media and fermentation ability with five basic sugars were similar. An interesting finding of the colony characteristics of the isolates were observed. The ice cream isolates were able to produce yellowish colonies on Staphylococcus agar no. 110, characteristic metallic sheen colony on EMB agar and bright pink colored colony on MacConkey agar.

In Gram's staining, the morphology of the isolated bacteria exhibited Gram positive (violet colour) cocci arranged in groups or grape like clusters; short cocco bacilli or rods arranged in bundles and singly also and Gram negative (pink colour) small rod-shape, arranged in single or pair which were supported by several authors (Buxton and Fraser, 1977 ).

In the present study, biochemical tests which were used for characterization of bacterial pathogens also used by Ali et al. (2008). Among two isolates, E. coli produce acid and gas by fermenting various sugars and gave positive reaction to indole, Motility Indole Urease, Methyl red and Catalase test but negative reaction to Voges Proskeur test which satisfy the statement of Buxton and Fraser. (1977). Staphylococcus spp. produce acid but no gas by fermenting various sugars and gave positive reaction to Catalase and Methyl red test but negative reaction to indole and Voges Proskeur test.

\section{Conclusion}

In Bangladesh unfortunately it is very difficult to monitor how the consumer can be affected by taking ice creams. From the present study, it was concluded Kwality ice creams are of the superior quality product in respect of sanitary condition in Bangladesh. However, much attention is still needed to apply in aspects of microbiological quality control for attaining desired safety margins and giving assurance that the ice cream product received by the consumer will be pure, healthful and of the quality claimed. To do so useful and effective legislation must have to be enacted and enforced, the chief aim of which is to ensure that the production, handling, processing, distribution and storage of ice cream could be maintained under strict hygienic control to protect consumers against health hazard and under quality standards. The government authorized institute (like BSTI) should take intensive investigation to control the microbial and chemical quality of the ice creams as well as the public awareness about the adulterated ice creams should be increased.

\section{References}

Ali, L. Muhammad, G. Arshad, M. Saqib, M. and Hassan, I. J. (2008). Bacteriology of mastitis in milch cows in Tehsil Samundri of District Faisalabad, Pakistan. Pakistan Veterinary Journal. 28: 31-33.

Bhusan Reddy, B.B. Kotinlinga Reddy, Y., Ranganadham, M. and Padmanabha Reddy, V. (1994). Bacteriological quality of ice cream marketed in Tirupati a pilgrimage town of India. J Food Sci. \& Tech. 31, 151-152.

BSTI. 2005. Bangladesh Standard and Testing Institute (BSTI). Dhaka.

Buxton, A. and Fraser, G. (1977). Animal Microbiology. Vol. 1. Blackwell Scientific Publications, Oxford, Lond. PP. 177-183.

Carter, G.R. (1979). Diagnostic Procedures in Veterinary Bacteriology and Mycoplasma. 3rd edn. Charles C. Thomas Publisher U. S. A. pp. 398-417.

Centers for Disease Control and Prevention (CDC) (1994). Outbreak of Salmonellaenteritidis associated with nationally distributed ice cream products--Minnesota, South Dakota, and Wisconsin. MMWR Morb Mortal Wkly Rep. 43 (40): 740-741.

FAO, 1995.Milk and dairy products in human nutrition. Series FAO: Food and Nutrition-28, 271.

Gran HM, AN Mutukumina, A Wethlesen and JA Narvhus, 2002. Smallholder dairy processing in Zimbabwe: the production of fermented milk products with particular emphasis on sanitation and microbiological quality. Food control, 13:161168.

Hassainya I, M Padilla and S Tozanli, 2006. Milk and milk products in the Mediterranean:Sectors a major restructuring. Morocco. Ed:KARTHALA, pp: 65.

Joshi, D.R. Shah, P.K., Manandhar, S. Sharma, S., and Banmali, P. (2004). Microbial quality of ice cream sold in Kathmandu. Journal of Nepal Health Research Council. 2: 37-40

Kanbakan,U.Con, A.H. and Ayar, A. (2004). Determination of microbiological contamination sources during ice cream production in Denizli, Turkey. Food Control.15 : 463-470.

Kokkinakis, E. and Fragkiadakis, G.A. (2007). HACCP effect on microbiological quality of minimally processed vegetables: a survey in six masscatering establishments. International Journal of Food Science and Technology 42: 18-23.

Merchant, I A. and Packer, R. A. (1967). Veterinary Bacteriology 
and Virology. Seventh edi. The Iowa University Press, Ames, Iowa, USA, pp. 286-306.

Orallo, G.O. Pangan, A.H. and Cabrera, E.C. (1999). Microbiological analysis of ice cream produced by big scale and small scale manufactures in Metro Manila. Phil J Microbiol Infect Dis. 28: 99-101.

Soriano, J.M. Rico, H. Molto, J.C. and Manes, J. (2002). Effect of introduction of HACCP on the microbial quality of some restaurant meals. Food Control,.13: 253-261.

Swanson, K.M.J. and Anderson, J.E. (2000). Industry perspective on the use of microbial data for HACCP validation and verification. J Food Prot. 63 : 815-818

Torkar, K.J. and Mozina, S.S. (2000). Differentiation of Bacillus cereus isolates from milk and milk products with biochemical, immunological, AP-PCR and PCRRFLP methods. Food Technology and Biotechnology. 38: 135-142

Vought, K.J. and Tatini, S.R. (1998). Salmonella enteritidis contamination of ice cream associated with a 1994 multistate outbreak. J Food Prot. 61 (1): 5-10.

WHO (1998). Strategies for Implementing HACCP in Small and/or Less Developed Business. Report of a WHO Consultation. WHO/SDE/PHE/FOS/Geneva. 